HOW

Volume 28, Number 2, pages 97 - 119

https://doi.org/10.19183/how.28.2.555

重OW

\title{
Theme-Based Teaching to Promote Oral Fluency in a University in Colombia
}

\author{
La Enseñanza basada en temáticas para promover \\ la fluidez verbal en una universidad en Colombia
}

\section{Angela Patricia Velásquez-Hoyos ${ }^{1}$}

\begin{abstract}
The present qualitative study with an action research orientation focuses on the strengthening of students' oral fluency in English through the implementation of six theme-based teaching workshops. The participants were students of an EFL pre-intermediate English language course in the institute of foreign languages at the Technological University of Pereira, in Risaralda State, Colombia. Besides the implementation of theme-based teaching, this study includes the speaking phases of rehearsal, performance, and debriefing to impact students' oral fluency. This project emerged from an exhaustive needs analysis which showed that the university's students, as future professionals, had difficulties with their oral performance i.e. their being unable to speak about topics related to their university life in English; hence, the need of including themes aligned with their academic contexts was highlighted with the purpose of helping them improve their oral fluency in English. The findings indicate that the students improved in their oral fluency in terms of vocabulary, intonation, and a reduction in the number of long pauses when speaking in English.
\end{abstract}

Keywords: oral fluency, smoothness of speech, speaking skill, theme-based teaching, university students, vocabulary range

\section{Resumen}

El presente estudio es una investigación cualitativa con una orientación de investigación-acción que trata sobre la implementación de seis talleres basados en la metodología de enseñanza por temas

She holds a Master in English Didactics from Universidad de Caldas. She is an adjunct professor in the Bilingual Teaching Program at Universidad Tecnológica de Pereira UTP. She recently coordinated the bilingual project in this department. She was a Fulbright scholar at Ferrum College, Virginia, in 2017-2018.

anpavelasquez@utp.edu.co

ORCID ID: https://orcid.org/0000-0002-9743-5769

Received: March 25th, 2020. Accepted: January 22nd, 2021.

This article is licensed under a Creative Commons Attribution-Non-Commercial-No-Derivatives 4.0 International License. License Deed can be consulted at https://creativecommons.org/licenses/by-nc-nd/4.0 
para fortalecer la fluidez oral de los estudiantes. Los participantes eran estudiantes de un curso de inglés EFL pre-intermedio del instituto de lenguas extranjeras de la Universidad Tecnológica de Pereira, en el departamento de Risaralda, Colombia. Además de la implementación de la enseñanza basada en temas, este estudio incluye las fases orales de ensayo, desempeño y reflexión para impactar la fluidez oral de los estudiantes. Este proyecto surgió a partir de un exhaustivo análisis de necesidades que mostró que los estudiantes universitarios, como futuros profesionales, tenían dificultades en su desempeño oral y no podían hablar sobre temas relacionados con su vida universitaria; de ahí que se resalte la necesidad de incluir temas alineados con sus contextos académicos con el propósito de ayudarlos a mejorar su fluidez verbal. Los hallazgos indicaron la mejora de los estudiantes en su fluidez en aspectos como vocabulario, entonación, así como una reducción en el número de pausas largas al hablar.

Palabras clave: conexión en el discurso, fluidez verbal, estudiantes universitarios, la habilidad de hablar, la enseñanza basada en temáticas, vocabulario

\section{Introduction}

As part of internationalization processes, universities in Colombia are making efforts to help students to achieve better competences in a foreign language, namely, English. Thus, with the purpose of enabling students to be part of international mobility programs, they need to strengthen their professional profile with different skills. Most of these programs require high English language proficiency levels, especially in oral fluency. In fact, The National Accreditation Council (2020), the governing body that establishes the criteria that higher education in Colombia must follow, includes internationalization and second language learning as part of the requisites for accreditation. Therefore, universities in Colombia have adopted a second language policy that includes having students taking English language courses.

This is the case of the Technological University of Pereira in Colombia, a state university in Risaralda, Colombia, which, committed to help students to achieve better English language proficiency levels, offers free English language courses through its Institute of Foreign Languages. After conducting a needs analysis ${ }^{2}$, in one of those courses, difficulties in students' oral performance in English were identified; especially, problems with oral fluency. For example, students' speech had long pauses, they did not have enough vocabulary to talk about their academic life, and they could not have continuous speech because they used isolated words without being able to connect ideas. Since students were unable to talk about their academic experiences, a theme-based teaching approach seemed to constitute the strategy that could help students to accomplish better fluency and learn vocabulary to talk about their academic experiences in English. Hence, this study emerged as a need to

The data collection instruments used in the needs analysis stage were: a students' questionnaire, a journal completed by the teacher-researcher, an outsider observation carried out by an English language teacher, and students' artefacts in the form of recordings. 
assist students to improve their oral fluency while speaking in English and increasing their opportunities of participating in mobility programs.

The relevant role that oral fluency plays in the language classroom is undeniable, particularly, for undergraduate students who would like to pursue scholarships and/or job opportunities in national and international contexts. According to the Common European Framework of Reference for languages -CEFRL- (Council of Europe, 2018), oral fluency is a measure of how easily a person can interact and share ideas clearly in a speech (p. 191). For the purposes of this study, I regard oral fluency as a mean for university students, from different university programs, to grow professionally and be able to communicate in a second language. The aim of this study, then, is to analyze students' oral fluency process through constant reflection on the implementation of theme-based teaching in the English language classroom. Its importance relies on providing the research community, interested in the development of communicative abilities of English as a foreign language (EFL) learners, with a different understanding of a theme-based teaching approach to improve students' fluency components as range, connected speech, intonation, and pauses. In addition, this project excels at the possibility of encouraging EFL teachers to explore other alternatives in the class that facilitate the use of multiple strategies to overcome students' oral fluency problem. Another important consideration regarding this project is the contribution it can make to change students' perceptions toward the teaching of the English language. For university students, English is perceived as a requirement for graduation and not as an alternative to enrich their professional profile. After the implementation of this study, the participants could see the significance of learning English to be part of academic events where they need to have high levels of oral fluency. The following research question was raised in this study: To what extent can theme-based teaching lessons develop the oral fluency of a group of students in a pre-intermediate EFL course at a public university in Colombia?

\section{Conceptual Framework}

There are two key concepts in this study: oral fluency and theme-based teaching.

\section{Oral Fluency}

Nowadays, internationalization has become an essential word in different academic programs that are in the process of leading students toward professional networks. A good command of a foreign language, which involves the ability to communicate orally, can be an asset that facilitates becoming part of those networks. Consequently, there is a variety of strategies and approaches to develop students' speaking skills, mainly oral fluency. Koponen and Riggenbach (2000) define oral fluency as a performance phenomenon that includes the mastery of different components such as range, continuity, smoothness of speech, and 
intonation. In similar ideas, Derwing et al., (2004) state that oral fluency is correlated with other aspects such as length, frequency, distribution of silent pauses, and non-lexical fillers. In a study conducted by Lestari (2019), oral fluency, as part of the speaking skill, is perceived to be a challenging process because it demands the speaker's language knowledge and skills to be activated in real time. The ideas proposed by Lestari were also discussed by Harmer (2015) when he says that oral fluency is determined by the speaker's knowledge about the topic being addressed, the time for planning, and the familiarity of the speaker with the topic.

Different perceptions regarding oral fluency emerged from a study conducted by Herrera and González (2017); they clearly identify oral fluency as an assessment indicator of spoken production in English. These researchers point out that oral fluency is the skill which allows learners to express genuine ideas verbally; something considered on certification exams such as the International English Language Testing System (IELTS) in which fluency is connected to coherence as "fluency and coherence refer to the ability to talk with normal levels of continuity, rate, and effort and to link ideas and language together to form coherent, connected speech" (IELTS, n.d., p. 3). In the same vein, the Educational Testing Service (2020) in their TOEFL examination presents fluency as a "well-paced flow", and in the assessment rubric for oral tasks, fluency is assessed by criteria of delivery (p. 1). This definition proposed on the TOEFL exam is similar with the one provided on the MET exam (2020) in which fluency is assessed in the intelligibility and delivery descriptors.

Segalowitz (2010) differentiates three different types of oral fluency. The first type is cognitive fluency associated with speech production; it includes the knowledge of the topic. The second type is utterance fluency that refers to the components of oral fluency as smoothness of speech, intonation, and number of pauses. The last type is perceived fluency; this is the listener's impression about the speaker's efficient language production skills. Segalowitz's ideas can be complemented with what Richard and Schmidt (2010) propose. They similarly perceive fluency as the level of proficiency in communication that includes the cognitive ability to produce written and/or spoken language with ease; also, the ability to speak with clear, not perfect, pronunciation or grammar to produce continuous speech without causing problems in comprehending the message. Richard and Schmidt (2010) also mention that fluency provides the features that give oral speech the qualities of being natural and normal, including the use of pausing, rhythm, intonation, stress, rate of speaking, and 100 use of interjections and interruptions. Even though Richard and Schmidt (2010) clarify different elements necessary for achieving oral fluency, their definition does not specify types of fluency as Segalowitz's (2010) does.

Related ideas about oral fluency components come from Blevins (2001), who points out that oral fluency has some components that let teachers know if a student is fluent or not at speaking in English. This author explains that the fluency components are smoothness of speech, intonation, and phrasing. Smoothness of speech refers to accurate, quick word, 
grammar, and topical recognition and connection to express ideas clearly. Blevins (2001, as cited in Cadavid \& Jimenez (2017) expresses that:

Although students may recognize words, their oral speech may be expressionless and/or lack coherence. Accuracy deals with the correct use of the grammatical aspects of the language. Intonation has to do with the speakers' ability to use the appropriate words with an effective tone of voice for the audience [to] understand the main points of a speech. Finally, phrasing is related to the ability to re-state and re-organize the main ideas of the speech with the purpose of clarifying ideas. (p. 49)

Gatbonton and Segalowitz (2005) highlight that oral fluency should focus on the development of smooth speech, intonation, tone of voice, and rapid language use that is mostly mastered through repetitive practice and oral class participation. That is why this research paper considers that to build up oral fluency, students require certain components such as vocabulary range, smoothness of speech, natural pauses, intonation, and class participation. Cadena-Aguilar et al., (2019) explain the importance of working on all these components to be fluent. Thus, this research implemented theme-based teaching workshops as this approach proposes the inclusion of contextualized topics, tasks, and materials that enable learners to follow examples of fluent conversations and speakers.

\section{Theme-Based Teaching}

The theme-based teaching model is derived from content-based instruction, which has been implemented worldwide to teach subject matters instead of teaching the language structures in isolation. Cameron (2001) argues that, in theme-based teaching, students can practice the language through content that is connected to their real context. This teaching approach provides realistic and motivating uses of the language with meaning and purpose as learners learn content that they can use in their real lives. Cameron (2001) also states that theme-based teaching facilitates learners to become more proficient in a language as it allows them to strengthen language skills because they learn the language in context and not in isolation.

Brinton et al., (2001) explain that in the theme-based approach, there is a selection of topics or themes that provide the content from which teachers extract language learning activities that suit students' real context and necessities; in the case of this current study, university students who are required to take certification exams and participate in academic events. Chamot and O’Malley (1990, as cited in Brinton \& Snow, 2003) propose a series of stages when planning lessons based on content; they suggest that it is important to begin the class by setting the stage; this means that the facilitator will activate students' background knowledge. The second stage is providing input, in which students are exposed to the content and the grammar presented in an implicit and contextualized way. Once the input is provided, 
students will participate in a guided practice, in which students work in small groups developing a specific task that is under the teacher's guidance. Then, students continue with an extension activity, in which they need to carry out a specific task, for which the use of the content learnt in the class is evident.

In a study conducted by Tussa'diah and Nurfadillah (2018), theme-based teaching is conceived as a vehicle for teaching the language and content; that creates a sense of students' interest and enthusiastic participation as they are talking about themes of their interest. In a different study developed in the Colombian context, Padilla (2016) states that when working with theme approaches, there needs to be an integration of the content with the language and the teaching objectives. In this paper, the theme-based approach is perceived as an alternative that will give students the possibility to learn new vocabulary and increase their level of oral fluency through the implementation of the speaking phases proposed by Di Pietro (1987), namely: rehearsal, performance, and debriefing. In the rehearsal phase, students prepare themselves for the speaking task, writing some notes, and asking their partners and teachers for help. In the performance phase, students speak about the theme they rehearsed and learnt in the lesson. In the debriefing phase, peer correction, self- assessment, and reflection are fostered. There are some guiding questions to activate students' self-reflection about their fluency during the performance.

\section{Methodology}

This section aims at explaining the methodological procedures implemented in this research study.

\section{Participants}

Seventeen students at a public university in Pereira, Colombia, were the participants of this study, which was developed in a pre-intermediate EFL summer course in the Institute of Foreign Languages (ILEX) at the Technological University of Pereira in Colombia. This course was taken by students during their vacation time $e^{3}$; that is why it is called a summer course. The students enrolled in the course consisted of seven males and ten females whose 102 ages ranged from 17 to 35 years old. These students belonged to different academic programs of the university, as children pedagogy, environmental sciences, industrial technology, ethnoeducation and social development, and veterinary medicine. Concerning students' English language background, they were exposed to English for over a year. Each English language course is sixty-four hours per semester, four hours weekly; these students were at an A2

A period in which students are not studying their academic semesters, but universities offer summer courses that students take to help them enrich their professional development. 
English language proficiency level having as a reference the standards proposed by the CEFRL.

\section{Data Collection Instruments}

During the development of this action research, I completed a journal that provided me with thoughtful insights about the class. In this journal I wrote information regarding the development of the class, oral tasks proposed for each workshop, the students' oral performance and oral participation. In this study, I used my journal as an instrument to collect this information since I wanted to have pieces of evidence from my own point of view as the teacher and researcher.

For this study, registering the data from another perspective was also necessary, in this case, an English language teacher completed an observation form (see Appendix A) that mainly aimed at documenting information such as the students' preparation, performance, and oral participation in each session as well as their reflection before, during, and after the speaking task. These observations were done every class for six workshops.

Moreover, to explore students' perceptions toward the class and their oral performance, I administered a questionnaire; this included eight questions that enabled students to reflect upon their oral performance. This questionnaire was administered in each session (see Appendix B).

Additionally, to accomplish the purpose of this research study, a number of the students' artifacts were collected to identify and reflect upon their achievements regarding their oral fluency in English. These students' artifacts came in the form of recordings, videos, and pictures, and they were gathered in the diagnosis and action stages (see Research Design below).

Finally, to assess students' oral performance, I designed a rubric with the following fluency aspects: intonation, vocabulary, smoothness of speech, and long pauses. At the end of each oral intervention, as the facilitator of the course, I assigned a grade from 1.0 as the lowest to 5.0 as the highest (see Appendix C).

\section{Research Design}

The research methodology of this study was developed from an action research perspective following the steps proposed by Burns (2010): planning, action, observation, and reflection. Burns (2010) describes the planning as the process of identifying the problem that students have; the second step, action, has to do with the pedagogical intervention the teacher researcher implements to solve the teaching situation. In observation, the teacher researcher collects the data that comes from the interventions. In the reflection step, the 
teacher researcher reflects on, evaluates, and describes the effects of the action to make sense of what has happened.

I started with the identification of the problem which was the lack of students' oral fluency in English. Once I identified the problem, I started to read some literature to learn the best strategy to solve this problem. Since the participants of this project belonged to different university programs, the implementation of a strategy that would enable them to talk about their academic programs and participate in academic events, such as symposiums and congresses, was necessary. That is why, after the revision of theory and literature, themebased teaching seemed to be the strategy to follow with the participants as this suggests teaching different themes through situations that are familiar to the learners.

\section{Planning: Diagnosis Stage}

One of the graduation requirements for students at the Technological University of Pereira is to take a proficiency English language examination that assesses reading, writing, listening, and speaking skills. This examination is adapted from the Key English Test (KET). After the analysis of students' results in semesters 2018-2 and 2019-1, I found that, on average, students had similar difficulties in the four skills, with a slightly lower result for the speaking skill, as shown in Figure 1.

Based on the results of the English language proficiency test, I conducted a diagnosis in the pre-intermediate EFL course to corroborate whether these students still had the same difficulties. To analyze the data, I followed the parameters proposed by Creswell

Profiency Test Results: October 2018, March 2019, May 2019

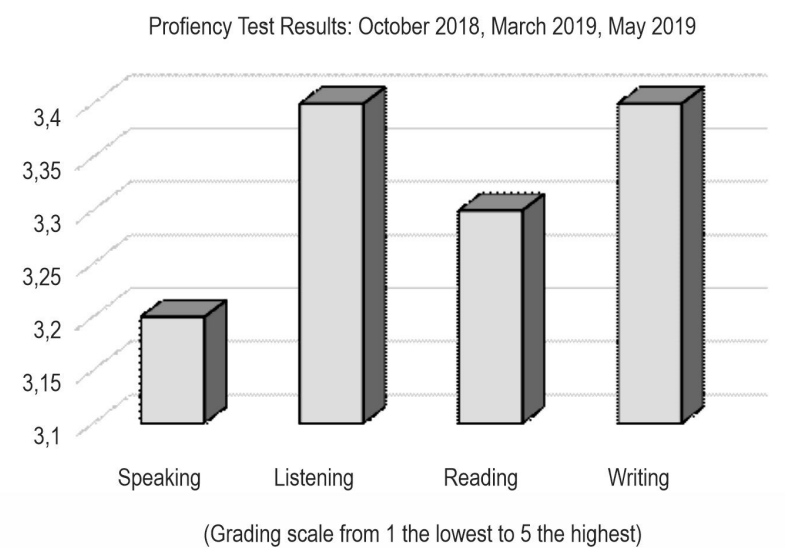

Figure 1. Proficiency Test Results from 2018-2 and 2019-1 
(2008), who mentions that there is a need to digitalize and codify the information, generate categories, and count the number of occurrences of each category throughout the instruments; therefore, the data can be quantified using numbers and percentages to be analyzed and later described.

After the data analysis, the main difficulties identified consisted of the students' problems as regards communicating ideas orally in English, their lack of speech-coherence evident in the use of isolated sentences or words, and their use of a great number of long pauses when performing a speaking task in English. The diagnosis proved that speaking was not only an issue for the proficiency test takers at the university, but for the students who were taking the pre-intermediate English course. After reading the data, I came across four categories that were frequently repeated in each instrument: problems with vocabulary range, problems in pronunciation, as well as difficulties with oral fluency and absence of oral participation. Table 1 below illustrates the number of occurrences each category had after counting the number of times these were repeated in each data collection instrument; therefore, it was paramount to take actions to overcome this issue.

Table 1. Diagnostic Stage Results

\begin{tabular}{|c|c|c|c|c|}
\hline \multicolumn{4}{|c|}{ Speaking Difficulties } & \multirow{3}{*}{$\begin{array}{c}\text { Frequencies } \\
\text { Totals }\end{array}$} \\
\hline \multirow[b]{2}{*}{ Categories } & \multicolumn{3}{|c|}{ Data Collection Instruments } & \\
\hline & $\begin{array}{c}\text { Teacher's } \\
\text { journal }\end{array}$ & $\begin{array}{l}\text { Outsider } \\
\text { Observer }\end{array}$ & $\begin{array}{c}\text { Ss' } \\
\text { Questionnaire }\end{array}$ & \\
\hline $\begin{array}{l}\text { Problems with } \\
\text { vocabulary range }\end{array}$ & 2 & 3 & 1 & 6 \\
\hline Problems in pronunciation & 1 & 2 & 1 & 4 \\
\hline Difficulties with oral fluency & 9 & 9 & 15 & 33 \\
\hline Absence of oral participation & 2 & 2 & 2 & 6 \\
\hline
\end{tabular}

\section{Action}

The intervention for this study started with the methodological design of six workshops within the framework of the theme-based teaching approach. Workshops included the following themes: Daily university life, social life at university, an academic experience, a trip to a natural park, making predictions about living and nonliving objects, and comparing interesting facts. These themes were selected based on the syllabus of the course and the participating students' 
consensus. The workshops were designed based on the stages provided by Chamot and O'Malley (1994), previously explained in the conceptual framework section above: provided input, free participation, and extension.

Table 2. Description of the Intervention

\begin{tabular}{|l|l|l|}
\hline \multicolumn{1}{|c|}{ Theme } & \multicolumn{1}{c|}{ Task } \\
\hline $\begin{array}{l}\text { Workshop 1: Daily } \\
\text { university activities }\end{array}$ & College life & $\begin{array}{l}\text { Creating a 2-minute conversation } \\
\text { expressing usual activities } \\
\text { students do at university. }\end{array}$ \\
\hline $\begin{array}{l}\text { Workshop 2: Social } \\
\text { life at university }\end{array}$ & $\begin{array}{l}\text { Is social life important } \\
\text { at university? }\end{array}$ & $\begin{array}{l}\text { Creating a 3-minute photo-story } \\
\text { based on 10 pictures taken. }\end{array}$ \\
\hline $\begin{array}{l}\text { Workshop 3: An } \\
\text { academic experience }\end{array}$ & $\begin{array}{l}\text { Anecdotes in my } \\
\text { professional degree }\end{array}$ & $\begin{array}{l}\text { For 3 minutes, talking about an } \\
\text { academic experience at the university. }\end{array}$ \\
\hline $\begin{array}{l}\text { Workshop 4: A trip } \\
\text { to a natural park }\end{array}$ & Types of animals & $\begin{array}{l}\text { Planning a 4-minute conversation } \\
\text { about a trip to a national park. }\end{array}$ \\
\hline $\begin{array}{l}\text { Workshop 5: Making } \\
\text { predictions }\end{array}$ & $\begin{array}{l}\text { Are you optimistic or } \\
\text { pessimistic about the future? }\end{array}$ & $\begin{array}{l}\text { Preparing a 5-minute } \\
\text { speech explaining some } \\
\text { predictions for the future. }\end{array}$ \\
\hline $\begin{array}{l}\text { Workshop 6: } \\
\text { Comparing } \\
\text { interesting facts }\end{array}$ & $\begin{array}{l}\text { Landmarks and } \\
\text { natural wonders }\end{array}$ & $\begin{array}{l}\text { Giving a 5-minute presentation } \\
\text { by making comparisons } \\
\text { about world facts. }\end{array}$ \\
\hline
\end{tabular}

For the extension part, in which the students would perform orally, I included three speaking phases suggested by Di Pietro (1987): rehearsal, performance, and debriefing. In the rehearsal phase, I practiced the vocabulary learnt with the students; they could have the chance of listening, watching, or checking a model of speech. They analyzed the model, took some sentences, or analyzed if the person used anecdotes or questions to engage the audience. Once we checked some samples, in the rehearsal, the students wrote ideas and practiced pronunciation. As the facilitator of the course, I monitored and assisted the students in this phase.

In the performance phase, the students presented their speaking task. While they were presenting it, I videotaped them and completed the assessment rubric that I designed to assess students' oral performance (see Appendix C). In the last phase, debriefing, the students worked in pairs and provided peer feedback by mentioning aspects they did well on or fairly well. Then, I provided the students with general feedback by emphasizing 
elements of fluency as intonation, pauses, cohesion of ideas, etc. The students were asked to answer these questions: What went well? What did not go so well? What was the most interesting thing of your speech? What was the most challenging aspect of your speech? These questions fostered the students' discussion, self-reflection, and comments on their oral fluency and language learning.

\section{Observation}

In this stage, after the development of each workshop, I analyzed the students' speaking performance based on the entries in the journal that I wrote for the study, the outsider's observation, the students' answers in the questionnaire, and the points that each student got in the assessment rubric. To analyze the data provided by these instruments, I considered the a priori data analysis. In this type of analysis, the codes are developed before examining the current data; it means that these are pre-established. Creswell (2009) argues that a priori analysis is carried out to delimitate the data and to avoid losing the focus of the research. The codes I predetermined before the data analysis are shown in Table 3.

\section{Reflection}

This is the last stage proposed by Burns (2010) in action research. Every workshop was an opportunity to see what the students needed in order to develop their fluency; I evaluated the way theme-based teaching developed the students' oral fluency in every single lesson. I made decisions and changes for further interventions.

\section{Results}

I present the results according to the information collected in the six workshops. The first result has to do with vocabulary range and how this fluency component helps the students to be better at performing orally in English. The second result deals with oral participation as a key element for oral fluency in English. The third result describes the significant reduction in the number of long pauses while the students were speaking in English; the fourth explains the importance of intonation having a balance in the tone of voice, and the last one has to do with students' ability to connect ideas when speaking in English. The following table summarizes the analysis done from workshop 1 to workshop 6 by counting the number of occurrences that each code was repeated in the data collection instruments.

The previous table indicates the significant development that the implementation of theme-based teaching workshops had on the participating students' oral fluency and its components: vocabulary range, oral participation, pauses, intonation, and smoothness of speech. This significant development is explained as follows. 
Table 3. Intervention Results: Data Triangulation from the Six Theme-Based Teaching Workshops

\begin{tabular}{|c|c|c|c|c|c|c|c|c|}
\hline \multirow[t]{2}{*}{ Codes } & \multirow[t]{2}{*}{ Operationalization } & \multicolumn{6}{|c|}{$\begin{array}{l}\text { Workshops } \\
\text { Frequencies }\end{array}$} & \multirow[t]{2}{*}{ Tota } \\
\hline & & W1 & W2 & W3 & W4 & W5 & W6 & \\
\hline $\begin{array}{l}\text { 1. Students' effective } \\
\text { use of vocabulary } \\
\text { through themes }\end{array}$ & $\begin{array}{l}\text { Code describes the use of } \\
\text { the appropriate vocabulary } \\
\text { at the moment of speaking. }\end{array}$ & 16 & 17 & 17 & 22 & 30 & 42 & 144 \\
\hline $\begin{array}{l}\text { 2. Positive class } \\
\text { participation }\end{array}$ & $\begin{array}{l}\text { Code describes the } \\
\text { students' interest towards } \\
\text { the class represented in } \\
\text { the students' willingness } \\
\text { to participate orally } \\
\text { and improve fluency. }\end{array}$ & 0 & 7 & 9 & 11 & 14 & 14 & 55 \\
\hline $\begin{array}{l}\text { 3. Students' long } \\
\text { pauses when talking } \\
\text { about themes }\end{array}$ & $\begin{array}{l}\text { Students' long pauses and } \\
\text { hesitation in the oral task. }\end{array}$ & 19 & 18 & 10 & 7 & 6 & 9 & 69 \\
\hline $\begin{array}{l}\text { 4. Students' lack of } \\
\text { intonation } \\
\text { while speaking }\end{array}$ & $\begin{array}{l}\text { Students had low } \\
\text { tone of voice, and } \\
\text { intonation problems. }\end{array}$ & 12 & 17 & 7 & 7 & 7 & 8 & 58 \\
\hline $\begin{array}{l}\text { 5. Students' lack of } \\
\text { smoothness of speech } \\
\text { while using themes. }\end{array}$ & $\begin{array}{l}\text { Students do not connect } \\
\text { their speech; they use } \\
\text { isolated sentences. }\end{array}$ & 12 & 13 & 10 & 5 & 6 & 2 & 48 \\
\hline \multicolumn{2}{|l|}{ Total } & 59 & 72 & 53 & 52 & 79 & 75 & 374 \\
\hline
\end{tabular}

\section{Theme-Based Teaching to Increase the Students' Vocabulary Range}

One of the paramount benefits of the implementation of theme-based teaching workshops is the impact it has on expanding students' range. 'The first category, Students' effective use of vocabulary through themes, indicates that, as shown in Table 3, vocabulary increased progressively from workshop 1 to workshop 6. In workshops 1,2 , and 3, there were no changes concerning this fluency component; however, there was an outstanding improvement

108 in workshops 4, 5, and 6. This category displays the highest number of occurrences from the analysis of the instruments applied in each workshop demonstrating that during the development of the interventions, the students gained new vocabulary that allowed them to express their opinions, establish discussions, describe, and participate actively in the lesson activities. This is explained by the outside observer:

The students are using previous knowledge and vocabulary they have learned in the course. They expressed their ideas using words from other classes; that has facilitated them to speak without too much hesitation and pauses. [sic] (OB4) 
Not only did the students improve their vocabulary but also they learnt the importance of practicing it in each lesson. At the end of the interventions, the improvement that the students reported was evident since they could recycle the vocabulary in the speaking tasks. As the workshops included an integration of language skills, the students could also recognize and use the vocabulary that was given in the different tasks such as reading a story, listening to a radio program, and writing an e-mail. One student expresses the importance of recycling vocabulary in their oral activities:

In this course, I learnt vocabulary. I like so much because I could use the vocabulary learnt in class one in other classes, so that me ayudo [helped me] to remember it and use it easily when I was speaking. [sic] (ST8)

I highlight the fact that the implementation of theme-based teaching facilitated the learning of new vocabulary that was contextualized to the students' interests, needs, and context; a situation that enabled them to be better at performing tasks related to their academic programs. One student explains it this way:

All the vocabulary and the speaking activities I have learnt in the class have helped me in my degree. That is why, I am very sure that this will help me when I will be working. [sic] (ST5)

Another significant outcome that springs from the applicability of the six workshops based on themes is how much this helped the students to be more proficient in the English language, particularly in vocabulary. This proficiency may allow them to get better job opportunities; consequently, they will likely have more alternatives to grow personally and professionally as manifested by a student as follows:

English is the universal language that is why, knowing vocabulary and speaking English well helps me to find a better job; particularly, this class has helped me to learn vocabulary about my program and improve the way I speak, and I am very sure that this skill will belp me in my career. [sic] (ST3)

\section{The Impact of Theme-Based Teaching on the Students' Oral Participation}

The second category displayed in Table 3 is Positive class participation. When the students participated orally in English in class, they had more chances to improve their speaking performance in this language; thus, oral participation is a benefit that theme-based teaching has on the students' oral fluency in English. Even though this category did not have a high number of occurrences in workshops 1, 2, and 3, it began to increase in workshops 4, 5, and 6. Themes such as types of animals and social life at university encouraged the students to talk and practice some of the vocabulary in English that they had usually learned in their academic programs. Additionally, the evidence gathered showed that the students' oral participation helped them gain oral fluency in English. This is notable from an excerpt taken from the outside observer in workshop 6: 
Students participate during the class very actively. They take the initiative to participate and it is evident that they want to practice grammar because they ask the teacher if what they are saying is correct or not. They also respond to elicitation very well and it is seen progress in terms of speaking skills and students' fluency. [sic] (OBS6)

The students also responded effectively to elicitation impacting significantly their oral participation and fluency in English, as shown in this piece of evidence from my journal in workshop 4:

Students participate during the class very active. They respond to elicitation very well and it is seen progress in terms of speaking skills and students' fuency. [sic] (Jou4)

In similar terms, the students agreed with the idea that having an active oral participation in class helped them achieve better levels of oral fluency in English. In workshop 5, one student responded:

I think that the classes helped me to improve my class participation because the topic of the class was interesting, and this engaged me to participate orally and to be more prepared when I had to speak. [sic] (ST1)

\section{Effective Use of Speech Pauses}

Another relevant outcome from the implementation of theme- based teaching workshops is the decrease of the students' long pauses while performing orally in English. Table 3 above illustrates the way the students' long pauses (when talking about themes) changed progressively from workshop 1, with 19 occurrences, to workshop 6 with 9 occurrences. Although the number of long pauses increased in workshop 6 in comparison to workshop 5, these pauses helped the students to have a better transition from one idea to another. At the initial point of the workshops, the students were unable to communicate ideas effectively, produce continuous speech, or connect ideas properly in English; they stopped without completing the idea. In workshop 1, one student answered:

In this class I felt that my oral performance was not good, I used the vocabulary learnt in class, but I stopped many times because I didn't know how to conectar [connect] the words and the ideas I wanted to say. [sic] (ST9)

At the end of the six workshops, the students were able to maintain the flow of the conversation, continuously speak about a topic, and think about a transition to continue with a different idea. The pauses that they made were positive because those assisted the students in reflecting how to connect ideas and use the appropriate vocabulary to present complete thoughts in their speech in English as indicated in the following excerpt from the observation in workshop 6 : 
Students' speeches have some pauses but they were able to continue speaking. They did not use isolated sentences, they stopped for a little time, but they were able connect their ideas and switch from one topic to another with coherence. [sic] (OB6)

The presence of pauses in the students' oral performance after the six workshops is a sign of their new language awareness; the students certainly engaged in pausing, but it enabled them to select the words and ideas that they wanted to express in English better.

\section{The Role of Theme-Based Teaching in the Students' Intonation}

In the category students' lack of intonation while speaking, the most successful outcome that the theme-based teaching implementation reported in terms of intonation was the improvement of the students' voice projection and tone of voice. As Table 3 displays, this category did not have a constant progression during the six workshops given the fact that, in each workshop, this had different ups and downs. The analysis of the collected data for the study demonstrated that, at the beginning of the intervention, the students knew little about how to intonate words and sentences properly in English, or how to phrase the words or how to raise or lower intonation in order to catch the audience's attention. The following entry taken from the outside observer in workshop 2 exemplifies this:

Students had difficulties with tone of voice and phasing. It was difficult to understand due to their voice projection. [sic] (OB2)

At the end of the intervention, the students made progress in their tone of voice. Therefore, tone of voice was a significant improvement for the participants of the study because the students listened to words in context and imitated intonation patterns. My journal in workshop 6 showed the progress that they made regarding intonation.

Students' intonation was outstanding. They had good voice projection and it was easy to understand what they said. They used a variety of fillers that made the speech more fuent; they played with the intonation to call people's attention. [sic] (TJou6)

The students then understood the importance of intonation, mainly tone of voice, in their speaking performance in English as a key feature of being a fluent speaker. In workshop 5, one student answered:

During my oral intervention, I had good intonation and pronunciation. In these classes, I improved a lot my tone of voice which made me sound more fluent: [sic] (ST3)

This excerpt explains how the implementation of theme-based teaching and the speaking phases of rehearsal, performance, and debriefing helped the students to reflect and overcome the major difficulties that they had in terms of intonation. The students expressed that they achieved a better speaking performance since playing with their tone of voice made their speeches sound more fluent in English. 


\section{Theme-Based Teaching to Build up the Students' Smoothness of Speech}

Smoothness of speech is one of the most relevant factors that influenced the development of oral fluency. It is true that range, intonation, and pauses play a vital role when building up oral fluency in English, as pointed out by Gatbonton and Segalowitz (2005). The category students' lack of smoothness of speech while using themes showed that the students were unable to connect ideas properly in workshop 1 , whereas, in workshop 6, only with 2 occurrences, they were more coherent at the moment of speaking in English. Thus, they could switch from one idea to the other by using proper vocabulary, intonation, and pauses. This is evident in the outside observer's notes in workshop 5.

Students spoke with coherence and appropriate flow. They used complete sentences and they connected them quickly. Their speeches were not made up of isolated sentences. It was a set of ideas that one leads to the other. [sic] (OB5)

At the beginning of the intervention, the students' speech in English lacked smoothness; they probably used certain vocabulary but showed long pauses and performance at the sentence level. They struggled to connect ideas, as noted in the following piece of data taken from the students' artefacts in workshop 1:

I usually, I have class in the morning. After class, eh I go to library a read a book, I go to do exercise, for example: eh fitness weight in the field, mmm also I like do friends, I like go to. [sic] (ST3)

After being exposed to six theme-based workshops, the students' speeches in English showed a high level of smoothness because they spoke with a certain degree of spontaneity. Additionally, the students could use the appropriate grammar and vocabulary in the right context, and transition words and English language fillers to move from one idea to the other. Being those characteristics relevant in a smooth speech, theme-based teaching facilitates the development of the students' oral fluency through contextualized lessons. The following is an example taken from the students' artifacts in workshop 6; it illustrates the students' progress from workshop 1 to workshop 6 .

In two days I am going to start studying my academic semester at the university. So far, I want to enjoy my holidays. For example, this afternoon I am going to read about different types of animals and their habitats because I want to be prepared for this semester that is about to start, by the way, I study veterinary. Eh in the weekend, I am going to visit my grandmother. She has many animals in her farm. She has cows, horses, pigs. For me horses are as big as the cows and the pigs are eh eh more small than the horses. For my next holidays I am going to travel to Cartagena. I consider that Cartagena is hotter than Pereira, but Cartagena I think. is bigger than Pereira. I am sure that in Cartagena I am going to see different animals as the sea horses, turtles and dolphins; they are all aquatic animals and need special conditions to live... [sic] (ST3)

In summary, the results of this research study demonstrate the meaningful influence that theme-based teaching had on the students' oral fluency in English. Throughout the workshops, students' progress was notable, mostly in the reduction of the number of long 
pauses, the effective use of vocabulary, the accomplishments in smoothness of speech, and the intonation in English. The implementation of theme-based teaching allowed the students to develop better levels of oral fluency, be able to express their opinions in class, create more elaborated and continuous speeches, and use proper intonation in English.

\section{Discussion and Conclusion}

The present study sought to know the extent to which theme-based teaching develops EFL pre-intermediate students' oral fluency in English. As shown in the previous section, the implementation of six theme-based workshops facilitated learning new vocabulary for the participants of the study; this helped them create ideas orally and participate in class more actively as themes were chosen. The findings of this study corroborate Tussa'diah and Nurfadillah's (2018) insights about theme-based teaching being a vehicle for activating oral participation in class as it progressively enables learners to build their oral fluency. Moreover, the outcomes of this study are in line with the work of Gatbonton and Segalowitz (2005), who explain that to foster oral fluency, working on different fluency components is necessary, as smoothness of speech, intonation, and tone of voice. Those are achieved through constant and contextualized language situations.

On the whole, the study revealed that when EFL learners are exposed to highly contextualized lessons, as theme-based teaching workshops, they have more opportunities to develop better levels of oral fluency as compared to learners exposed to traditional teaching in which grammatical structures are the focus of the lessons. Thus, one outstanding pedagogical goal of this study is to help learners understand the importance of oral fluency in English for their future professional career; as such, themes allow learners to know about different topics that are useful in a variety of academic, professional, and social contexts. Eventually, this will help learners to participate in mobility programs or get better job opportunities.

The findings of this study can be beneficial for English language teachers and curriculum planners since, to strengthen oral fluency, proper planning of oral activities, which also integrate other language skills, are paramount to fulfilling learners' needs, interests, and learning preferences. These help me create a positive classroom environment in which EFL learners can become willing to participate. Further studies need to be conducted to shed light on the best uses of the theme-based teaching approach within the ELT field.

Furthermore, the results of this study point to the significance of designing theme-based teaching workshops by means of improving classroom dynamics; as in this case, the lack of oral fluency in English. Action research is an appropriate way to help learners overcome a problem, so I open the invitation to English language teachers to explore this type of qualitative studies to help learners to improve and reflect on their language performance. 


\section{References}

Blevins, W. (2018). Fluency [PowerPoint presentation]. http://blevinsreading.weebly.com/fluency. html

Brinton, D. M., Snow, M. A., \& Wesche, M. (2003). Content-based second language instruction. University of Michigan Press.

Burns, A. (2010). Doing action research in English language teaching. A guide for practitioners. ESL \& Applied Linguistics Professional Series.

Cadavid, M., \& Jimenez, D. (2017). CLIL: Its effect on high school students' English speaking performance [Unpublished undergraduate dissertation]. Universidad Nacional Abierta y a Distancia.

Cadena-Aguilar, R. F., Ortega-Cuellar, J. H., \& Cadena-Aguilar, A. (2019). Daily 6: An approach to foster oral fluency of English as a foreign language in adolescents. Profile: Issues in Teachers' Professional Development, 21(2), 29-44. https://doi.org/10.15446/profile.v21n2.71364.

Cameron, L. (2001). Teaching languages to young learners. Cambridge University Press.

Consejo Nacional de Acreditación (2020). Acuerdo 02 de 2020 por el cual se actualiza el modelo de acreditación de alta calidad. https://www.cna.gov.co/1741/articles-186370_Acuerdo_02_2020_NUev_Modelo.pdf

Council of Europe (2018). Common European framework of reference for languages: Learning, teaching, assessment. Companion volume with new descriptors. Cambridge University Press.

Creswell, J. W. (2009). Research design: Qualitative, quantitative, and mixed methods approaches. Sage.

Derwing, T. M., Rossiter, M. J., Munro, M. J., \& Thomson, R. I. (2004). Second language fluency: Judgments on different tasks. Language Learning, 54(4), 655-679.

Di Pietro, R. J. (1987). Strategic interaction: Learning languages through scenarios. Cambridge University Press.

Educational Testing Service (2020). The official guide to the TOEFL test. https://www.ets.org/s/ toefl/pdf/toefl_speaking_rubrics.pdf

Gatbonton, E., \& Segalowitz, N. (2005). Rethinking communicative language teaching: A focus on access to fluency. The Canadian Modern Language Review, 61(3), 325-353.

Harmer, J. (2015). The practice of the English Language (5th ed.). Pearson.

Herrera Díaz, L. E., \& González Miy, D. (2017). Developing the oral skill in online English courses framed by the community of inquiry. Profile: Issues in Teachers' Professional Development, 19(1), 73-88. https://doi.org/10.15446/profile.v19n1.55957.

International English Language Testing System IELTS (n.d). Speaking test: How are band Scores awarded for Speaking? https://www.ielts.org/online-tutorial/four-skills/speaking/speakingtest-how-are-bandscores-awarded-for-speaking

Koponen, M., \& Riggenbach, H. (2000). Overview: Varying perspectives on fluency. In H. Riggenbach (Ed.), Perspectives on fluency (pp. 5-24). University of Michigan Press. 
Lestari, N. (2019). Improving the speaking skill by Vlog (video blog) as learning media: The EFL students' perspective. International Journal of Academic Research \& Social Sciences, 9(1), 915-925.

Michigan English Test MET (2020). Speaking scale. https://michiganassessment.org/wp-content/ uploads/2020/02/20.02.PDF.MET-Speaking-Scale.pdf

O’ Malley, J., \& Chamot, U. (1990). Learning strategies in second language acquisition. Cambridge University Press.

Padilla De La Cerda, F. (2016). The design of a theme-based and genre-oriented strategic reading course to improve students' reading comprehension skills at a public school in Colombia. HOW, 23(1), 49-67. https://doi.org/10.19183/how.23.1.143

Richards, J. C., \& Schmidt, R. (2010). Longman dictionary of language teaching and applied linguistics (4 ${ }^{\text {th }}$ ed.). Longman.

Segalowitz, N. (2010). Cognitive bases of second language fluency. Routledge.

Tussa'diah, H., \& Nurfadillah, K. (2018). The implementation of theme-Based teaching to improve students' achievement in narrative text. KnE Social Sciences / The 1st Annual International Conference on Language and Literature (AICLL), Universitas Islam Sumatera Utara (UISU), 18-19 April 2018, Medan, Indonesia, (pp. 352-360). https://doi.org/10.18502/kss.v3i4.1946 


\section{Appendix A. \\ Observation format}

\begin{tabular}{|c|c|c|c|c|c|}
\hline $\begin{array}{l}\text { Workshop } \\
\mathrm{N}^{\circ}\end{array}$ & $\begin{array}{l}\text { Development } \\
\text { of the class } \\
\text { (general } \\
\text { comments) }\end{array}$ & $\begin{array}{l}\text { Students' oral } \\
\text { participation } \\
\text { (general } \\
\text { comments) }\end{array}$ & $\begin{array}{l}\text { Oral fluency } \\
\text { task (General } \\
\text { comments) }\end{array}$ & $\begin{array}{l}\text { Fluency } \\
\text { process }\end{array}$ & Tick $\sqrt{ }$ \\
\hline & $\begin{array}{l}\text { Theme of } \\
\text { the class: }\end{array}$ & & Intonation: & \multirow{3}{*}{ Rehearsal } & $\begin{array}{l}\text { Students use the } \\
\text { target language: }\end{array}$ \\
\hline & & & Range: & & $\begin{array}{l}\text { Students ask other } \\
\text { students questions: }\end{array}$ \\
\hline & & & Pauses: & & $\begin{array}{l}\text { Students recycle } \\
\text { vocabulary they } \\
\text { already know. }\end{array}$ \\
\hline & \multirow{4}{*}{$\begin{array}{l}\text { Activities } \\
\text { and students' } \\
\text { response: }\end{array}$} & & \multirow{4}{*}{$\begin{array}{l}\text { Smoothness } \\
\text { of speech: }\end{array}$} & \multirow[b]{2}{*}{ Performance } & $\begin{array}{l}\text { Students' speech is } \\
\text { understandable. }\end{array}$ \\
\hline & & & & & $\begin{array}{l}\text { Students connect } \\
\text { ideas easily. } \\
\text { Students use the } \\
\text { right intonation. }\end{array}$ \\
\hline & & & & \multirow[b]{2}{*}{ Debriefing } & $\begin{array}{l}\text { Students recognize } \\
\text { mistakes. }\end{array}$ \\
\hline & & & & & $\begin{array}{l}\text { Students follow } \\
\text { teachers' } \\
\text { recommendations. }\end{array}$ \\
\hline
\end{tabular}




\section{Appendix B. \\ Students' questionnaire}

After completing the oral production task, reflect on your process before, during and after the activity. Answer the following questions according to your performance on the oral intervention.

1. During the planning of the oral activity, did you use the English language while speaking with your partners? How did you do it?

2. During the planning of the oral activity, did you require the help of a dictionary, partner, or the teacher? How useful was the help provided?

3. Did the presentation of the theme of the class help you in the creation of your ideas for the presentation of the oral task? Explain.

4. During the presentation, was it easy for you to present your ideas orally? Explain

5. Select an answer (a, b) according to the following sentence. During my oral intervention, I had good intonation and pronunciation.
a. Definitely not
b. Definitely yes

6. Select an answer $(\mathrm{a}, \mathrm{b})$ according to the following sentence. During the oral presentation, I had to stop my oral intervention frequently.
a. Definitely not
b. Definitely yes

7. Select an answer $(\mathrm{a}, \mathrm{b})$ according to the following statement. I used the vocabulary presented in class.
a. Definitely not
b. Definitely yes 
8. Select an answer (a, b) according to the following sentence. Suggestions from the teacher and my classmates helped me to perform better on my oral intervention.
a. Definitely not
b. Definitely yes

General Comments: Briefly describe your process before, during and after your oral intervention. 


\section{Appendix C. Teacher's assessment rubric}

Student's name:

\begin{tabular}{|l|l|l|l|l|l|}
\hline \multicolumn{1}{|c|}{ Criteria } & $\mathbf{1}$ & $\mathbf{2}$ & $\mathbf{3}$ & $\mathbf{4}$ & $\mathbf{5}$ \\
\hline $\begin{array}{l}\text { Range: Has a sufficient range of language to be able to } \\
\text { develop the task without much conspicuous searching for } \\
\text { words, using some complex sentence forms to do so. }\end{array}$ & & & & & \\
\hline $\begin{array}{l}\text { Intonation: Has a clear tone of voice that } \\
\text { makes the speech understandable and possible } \\
\text { to differentiate language chunks. }\end{array}$ & & & & & \\
\hline $\begin{array}{l}\text { Pauses: Can produce stretches of language with a } \\
\text { fairly even tempo; although he/she may hesitant as } \\
\text { she/he searches for patterns and expressions. }\end{array}$ & & & & & \\
\hline $\begin{array}{l}\text { Smoothness of speech: Can connect the ideas by using } \\
\text { appropriate rate, range, intonation and there are a few } \\
\text { pauses that do not affect the flow of the speech. }\end{array}$ & & & & & \\
\hline
\end{tabular}

\section{Global achievement}

$5=$ The criterion is fully accomplished.

$4=$ The criterion is accomplished although with a few mistakes.

$3=$ The criterion is barely accomplished, and a significant number of mistakes occur.

$2=$ The criterion is not accomplished, and many mistakes occur. Though, the presentation is possibly understood.

$1=$ The criterion is not accomplished, a huge number of mistakes occur, and the presentation is not easily understood.

Comments: 